\title{
PENGARUH CARA PEMUPUKAN NPK 15-7-8 BINTANG KUDA LAUT DAN PUPUKSUPERNASA TERHADAP PERTUMBUHAN DAN PRODUKSI TANAMAN JAGUNG (Zea mays L) \\ Elda Sari Siregar ${ }^{1^{*}}$, Suryanto $^{\left.2^{*}\right)}$ \\ ${ }^{1,2^{*}}$ Fakultas Pertanian Universitas Muhammadiyah Tapanuli Selatan, Sumatera Utara
}

\begin{abstract}
ABSTRAK
Penelitian ini dilaksanakan pada lokasi Kelurahan Sihitang Kecamatan Padangsidimpuan Tenggara Kota Padangsidimpuan. Penelitian ini bertujuan untuk mengetahui Pengaruh Cara Pemupukan NPK 15-7-8 Bintang Kuda Laut dan Pupuk Supernasa Terhadap Pertumbuhan dan Produksi Tanaman Jagung (Zea mays L). Rancangan yang digunakan dalam penelitian ini adalah Rancangan Acak Kelompok (RAK) faktorial dengan dua faktor yaitu Faktor Cara Pemupukan (C) Terdiri Dari 3 Taraf yaitu Menaburkan pupuk sekitar batang tanaman (C1),Dengan cara menugal (C2),Dengan Cara Larikan (C3). Faktor Pemberian Pupuk Supernasa (S) terdiri dari empat taraf yaitu : Kontrol (tanpa pupuk)S0,1,5gr/tanaman(S1), 2 gr/ tanaman (S2)dan 2,5 gr/ tanaman(S3). Dari hasil analisa secara statistik perlakuan cara pemupukan menunjukkan pengaruh yang nyata terhadap terhadap tinggi tanaman umur 3 , 5 , dan 6 mst, jumlah daun umur 3 mst, tetapi tidak menunjukkan pengaruh yang nyata terhadap tinggi tanaman umur 4 mst, jumlah daun umur 4, 5, dan 6 mst, produksi per sampel dan produksi per plot, perlakuan pupuk Supernasa menunjukkan pengaruh yang nyata terhadap tinggi tanaman umur 3, dan 6 mst, jumlah daun umur 4 mst, diameter batang umur 3, 4, 5 dan 6 mst, umur berbunga, produksi per sampel dan produksi per plot tetapi tidak menunjukkan pengaruh yang nyata terhadap tinggi tanaman umur 4, dan 5 mst, jumlah daun umur 5 dan 6 mst, interaksi kedua perlakuan menunjukkan pengaruh yang nyata terhadap tinggi tanaman umur 4, 5 dan 6 mst, jumlah daun umur 3 mst, tetapi tidak menunjukkan pengaruh yang nyata terhadap parameter tinggi tanaman umur 3 mst, jumlah daun umur 4, 5, dan 6 mst, produksi per sampel dan produksi per plot.
\end{abstract}

Kata Kunci : Pemupukan, bintang kuda laut supernasa, jagung manis 


\section{PENDAHULUAN}

Di Indonesia, jagung pertama kali datang pada abad 17, dibawa oleh bangsa portugis, Sejak kedatangannya, tanaman ini menjadi tanaman pangan utama kedua setelah padi yang ditanam hampir oleh seluruh petani di Nusantara, Bagi petani yang mengalami kegagalan panen padi karena serangan hama, menanam jagung menjadi alternative untuk mendapatkan keuntungan atau minimal untuk menutupi kerugian, (Agung S, 2008)

Jagung merupakan tanaman serealia penting sesudah gandum dan padi, areal pertanaman jagung mencakup daerah yang luas, dari mulai daerah tempratur subtropik dan tropik, Rendahnya hasil jagung terutama disebabkan karena belum meluasnya pemakaian varietas unggul, pemakaian pupuk terlalu sedikit dan tidak seimbang serta cara bercocok tanam yang belum sempurna (Sutoro, 2001),

Upaya peningkatan kualitas maupun kwantitas hasil pertanian melalui berbagai manipulasi telah dilakukan oleh para ahli pertanian dengan memuliakan tanaman, pengendalian hama dan penyakit tanaman serta melalui berbagai macam cara (teknik) pemupukan, Pemupukan pada dasarnya adalah usaha untuk memenuhi kebutuhan tanaman akan unsur hara agar berbagai proses fisiologis tanaman dapat berjalan dengan baik (Sutoro, 2001),

Peningkatan produktivitas tanaman jagung juga tidak terlepas dari pemupukan, Pupuk supernasa memiliki beberapa manfaat yakni :memperbaiki fisik, kimia dan biologi tanah, memberikan semua jenis unsur hara makro dan mikro lengkap, mengurangi penggunaan pupuk makro (N, P dan $\mathrm{K}$ ) sampai 50\%, merangsang pembungaan dan pembuahan, dan mengurangi kerontokan bunga dan buah, Pupuk ini juga memliki keunggulan antara lain : memperbaiki kerusakan tanah akibat pemakaian pupuk kimia terus menerus, menggemburkan dan menyuburkan tanah yang keras, mengurangi ketergantungan pupuk kimia 25\% - 50\%, mampu melarutkan sisa pupuk kimia dalam tanah agar bias diserap oleh tanaman, dan mempercepat pertumbuhan, pembungaan, pembuahan dan mengurangi kerontokan bunga/buah, 
Pupuk NPK 15-7-8 Bintang kuda laut merupakan pupuk majemuk blending yang didalamnya terkandung unsur nitrogen, fosfor dan kalium yang diramu dengan komposisi hara makro yang berimbang sesuai kebutuhan tanaman, Selain itu pupuk NPK 15-7-8 Bintang kuda laut sangat bermanfaat bagi tanaman antara lain : mempercepat pertumbuhan dan tinggi tanaman serta meningkatkan pembentukan jumlah anakan secara maksimal, pertumbuhan akar lebih cepat dan lebih lebat sehingga tanaman menjadi sehat dan kuat, fisik batang lebih tegak, kuat dan mengurangi resiko rebah, dan meningkatkan daya tahan terhadap serangan hama penyakit.

Selain itu upaya peningkatan produktivitas dan perluasan areal tanam akan berlangsung pada berbagai lingkungan atau agroekosistem beragam mulai dari lingkungan berproduktivitas tinggi (lahan subur) sampai yang berproktivitas rendah (lahan sub-optimal dan marjinal), Untuk itu diperlukan penyediaan teknologi produksi jagung yang beragam dan spesipik lingkungan, (Ahmad Suryana, dkk, 2007)

\section{BAHAN DAN METODE}

Penelitian ini dilaksanakan di Kelurahan Sihitang Kecamatan Padangsidimpuan Tenggara Kota Padangsidimpuan pada Ketinggian 500 meter dpl.

\section{METODE PENELITIAN}

Penelitian ini dilakukan dengan menggunakan Rancangan Acak Kelompok (RAK) faktorial dengan duafactor yaitu Faktor Cara Pemupukan (C) Terdiri Dari 3 Taraf yaitu Menaburkan pupuk sekitar batang tanaman (C1), cara menugal (C2), Cara Larikan (C3). Faktor Pemberian Pupuk Supernasa (S) terdiri dari empat taraf dosis yaitu Kontrol (tanpa pupuk) (S0), $5 \mathrm{gr} / \operatorname{tanaman}(\mathrm{S} 1), 2 \mathrm{gr} / \operatorname{tanaman}(\mathrm{S} 2)$ dan 2,5 gr/ tanaman( S3).

Model linier dari rancangan ini adalah :

$Y i j k=\mu+\rho i+\alpha j+\beta k+(\alpha \beta) j k+\Sigma i j k$ 
Yijk = Hasil pengamatan faktor $\mathrm{C}$ pada taraf ke-j dan faktor $\mathrm{S}$ pada taraf ke-k dalam ulangan ke-i

$\mu \quad=$ Efek dari nilai tengah

$\mathrm{i} \quad=$ Efek dari nilai blok pada taraf ke-i

$\alpha \mathrm{j}=$ Efek dari faktor $\mathrm{C}$ pada taraf ke-j

$\beta \mathrm{k}=$ Efek dari faktor S pada taraf ke-k

$(\alpha \beta)=$ Efek interaksi dari faktor $\mathrm{C}$ pada taraf ke-j dan faktor S pada tarap ke-k

$\Sigma$ ijk = Efek eror dari faktor C pada taraf ke-j dan faktor S pada taraf ke-k ulangan ke-I (Gomes,A.K and A.A Gomes, 1995).

Parameter yang diamati adalah Tinggi Tanaman (cm), jumlah daun (helai),Produksi Per Sampel (g), Produksi Per Plot (g)

HASIL

Berdasarkan hasil analisis statistik terhadap variabel pengamatanTinggi Tanaman (cm),jumlah daun (helai), Produksi Per Sampel (g), Produksi Per Plot (g)

Tabel 1: Hasil Interaksi Perlakuan Pengaruh Cara Pemupukan NPK 15-7-8 Bintang kuda laut dan Pupuk Supernasa Terhadap Tinggi Tanaman Umur 6 Minggu Setelah Tanam $(\mathrm{cm})$.

\begin{tabular}{|c|c|c|c|c|c|}
\hline Perlakuan & S0 & S1 & S2 & S3 & Rataan \\
\hline C1 & 61,2 & 62,1 & 64,1 & 64,8 & $252,2 \mathrm{a}$ \\
\hline C2 & 61,4 & 63,6 & 63,8 & 63,9 & $252,7 \mathrm{a}$ \\
\hline C3 & 61,9 & 64,5 & 65,5 & 65,3 & $257,2 \mathrm{a}$ \\
\hline Rataan & $184,5 \mathrm{a}$ & $190,2 \mathrm{a}$ & $193,4 \mathrm{a}$ & $194 \mathrm{a}$ & + \\
\hline
\end{tabular}

Keterangan : Angka yang diikuti huruf yang sama pada kolom dan baris menunjukkan berbeda nyata menurut Uji DMRT 5 \%,

Tabel 2 : Hasil Interaksi Perlakuan Pengaruh Cara Pemupukan NPK 15-7-8 Bintang kuda laut dan Pupuk Supernasa Terhadap Jumlah Daun Umur 6 Minggu Setelah Tanam (cm).

\begin{tabular}{|c|c|c|c|c|c|}
\hline Perlakuan & S0 & S1 & S2 & S3 & Rataan \\
\hline C1 & 10,7 & 11 & 11,3 & 11,7 & $11,17 \mathrm{abc}$ \\
\hline C2 & 10,7 & 12,2 & 11,7 & 12,3 & $11,6 \mathrm{ab}$ \\
\hline C3 & 10,7 & 11,7 & 12,1 & 12,0 & $11,6 \mathrm{a}$ \\
\hline Rataan & $10,7 \mathrm{c}$ & $11,56 \mathrm{a}$ & $11,66 \mathrm{~b}$ & $11,9 \mathrm{ab}$ & - \\
\hline
\end{tabular}

Keterangan : Angka yang diikuti huruf yang sama pada kolom dan baris menunjukkan berbeda nyata menurut Uji DMRT $5 \%$, 
Tabel 3: Hasil Interaksi Perlakuan Pengaruh Cara Pemupukan NPK 15-78 Bintang kuda laut dan Pupuk Supernasa Terhadap Produksi Per Sampel Umur 6 Minggu Setelah Tanam (cm).

\begin{tabular}{|c|c|c|c|c|c|}
\hline Perlakuan & S0 & S1 & S2 & S3 & Rataan \\
\hline C1 & 224,9 & 234,7 & 237,7 & 238 & 233,82 \\
\hline C2 & 227,5 & 234,2 & 237,2 & 241,81 & 235,17 \\
\hline C3 & 229,6 & 235,1 & 241,8 & 238,1 & 236,15 \\
\hline Rataan & 227,33 & 234,66 & 238,9 & 239,3 & \\
\hline
\end{tabular}

Keterangan : Angka yang diikuti huruf yang sama pada kolom dan baris menunjukkan berbedanyata menurut Uji DMRT $5 \%$,

Tabel 4 : Hasil Interaksi Perlakuan Pengaruh Cara Pemupukan NPK 15-7-8 Bintang kuda laut dan Pupuk Supernasa Terhadap Produksi Per Plot (gr)

\begin{tabular}{|c|c|c|c|c|c|}
\hline Perlakuan & S0 & S1 & S2 & S3 & Rataan \\
\hline C1 & 5690 & 5654 & 5685 & 5711 & 5685 \\
\hline C2 & 5564 & 5645 & 5698 & 5702 & 5652,25 \\
\hline C3 & 5572 & 5646 & 5668 & 5692 & 5644,5 \\
\hline Rataan & 5608,66 & 5648,33 & 5683,66 & 5701,66 & \\
\hline
\end{tabular}

Keterangan : Angka yang diikuti huruf yang sama pada kolom dan baris menunjukkan berbeda nyata menurut Uji DMRT 5 \%.

Dari hasil statistik perlakuan cara pemupukan NPK 15-7-8 Bintang kuda laut menunjukkan pengaruh yang nyata terhadap tinggi tanaman umur 3, 5, dan 6 mst, jumlah daun umur 3 mst, dan panjang tongkol, tetapi tidak menunjukkan pengaruh yang nyata terhadap tinggi tanaman umur 4 mst, jumlah daun umur 4, 5, dan 6 mst, produksi per sampel dan produksi per plot. hal ini diduga bahwa pada kondisi fisik dan kimia tanah yang optimal, sistem perakaran tanaman sepenuhnya dipengaruhi oleh faktor genetik, pupuk NPK 15-7-8 Bintang kuda laut dapat digunakan dalam memperbaiki struktur tanah, baik lingkungan fisik, kimia maupun biologisnya. Penyediaan unsur hara yang berasal dari pupuk NPK 15-7-8 Bintang kuda laut dapat mengoptimalkan kondisi media tanah sehingga perakaran dapat tumbuh dan menyerap unsur hara yang sesuai dengan kebutuhan secara genetik (Lakitan, 2001).

Hal ini mungkin terjadi akibat cara pemupukan yang dilakukan belum tepat atau pupuk yang diberikan dengan ketiga cara diatas belum tepat baik kedalam lubang atau lebar larikan dan juga jarak lingkaran dari tanaman, dengan demikian pupuk yang diberikan dengan dosis yang 
rendah atau kurang tidak langsung dimanfaatkan oleh tanaman secara keseluruhan, bisa saja karena terjadi persaingan dengan tanaman lain seperti gulma. Diduga cara pemupukan yang dilakukan tepat, sehingga dapat dimanfaatkan oleh tanaman sesuai untuk kebutuhannya, dalam penelitian ini dapat dilihat bahwa cara pemupukan NPK 15-7-8 bintang kuda laut yang paling baik adalah cara pemupukan dengan cara tugal.

Dari hasil statistik perlakuan pupuk supernasa menunjukkan pengaruh yang nyata terhadap tinggi tanaman umur 3 dan 6 mst, jumlah daun umur 4 mst, produksi per sampel, produksi per plot tetapi tidak berpengaruh nyata terhadap tinggi tanaman umur 4 dan 5 mst, jumlah daun umur 5 dan 6 mst. Pupuk supernasa dapat meningkatkan produksi tanaman melalui reaksi fermentasi yang menghasilkan asam organik, hormon tanaman, anti biotik dan polisakarida juga menjaga tanaman dari serangan hama dan penyakit. Pupuk supernasa juga memberikan pengaruh yang menguntungkan dalam pemanfaatannya antara lain : meningkatkan perkecambahan, bunga, buah dan kematangan hasil tanaman, memperbaiki lingkungan fisik, kimia, biologi tanah serta menekan pertumbuhan hama dan penyakit dalam tanah, meningkatkan kapasitas fotosintesis tanaman, menjamin perkecambahan dan pertumbuhan tanaman yang lebih baik, meningkatkan manfaat bahan organik sebagai pupuk (Anonimus, 1999).

Hal ini juga didukung dari keadaan unsur hara dalam tanah sesuai dengan hasil analisis tanah dimana kandungan : $\mathrm{N}=0,13 \%, 0,12 \%, 0,13 \%$. Kandungan Nitrogen dalam pupuk ini lebih rendah bila dibanding dengan unsur lainnya seperti unsur $\mathrm{P}$ dan $\mathrm{K}$, sebab unsur $\mathrm{N}$ adalah unsur hara makro yang dibutuhkan tanaman dalam jumlah banyak, diserap tanaman dalam bentuk amonium (NH4+). Peranan unusr nitrogen dalam merangsang pertumbuhan vegetatif dari tanaman membuat daun tanaman berwarna hijau gelap selain itu $\mathrm{N}$ merupakan penyusun plasma sel berperan dalam pembentukan protein. 
Hal ini juga didukung dari keadaan unsur hara dalam tanah sesuai dengan hasil analisis tanah dimana kandungan $\mathrm{P}=$ 9,53ppm, 4,04 ppm, 4,50 ppm. Unsur ini merupakan komponen tiap sel hidup dan cenderung terkonsentrasi dalam biji dan titik tumbuh tanaman. Unsur ini diserap dalam bentuk ion ortofosfat (H2PO4-) dan ion ortofosfat skunder (HPO4=). Peranan unsur $\mathrm{P}$ merangsang pertumbuhan akar terutama pada awal pertumbuhan mempercepat pembungaan, pemasakan biji dan buah dan berfungsi untuk pengangkutan energi hasil metabolism dalam tanaman. Kandungan $\mathrm{K}=0,120$ me/100, 0,258 me/100, 0,111 me/100. Tanaman menyerap kalium dalam bentuk ion $\mathrm{K}+$.kalium di dalam tanah ada dalam berbagai bentuk yang potensi penyerapannya untuk setiap tanaman berbeda-beda. Peranan unsur K dapat membentuk dan mengangkut karbohidrat, sebagai katalisator dalam pembentukan protein, mengatur pergerakan stomata, memperkuat tegaknya batang, membuat biji tanaman lebih berisi dan padat, meningkatkan kualitas buah, dan membuat tanaman menjadi lebih tahan terhadap hama dan penyakit.

Dari hasil statistik interaksi kedua perlakuan menunjukkan pengaruh yang nyata terhadap tinggi tanaman umur 4, 5, dan 6 mst, jumlah daun umur 3 mst, tetapi tidak berpengaruh nyata terhadap tinggi tanaman umur 3 mst, jumlah daun umur 4, 5, dan 6 mst, produksi per sampel, produksi per plot, Hal ini dapat terjadi disebabkan keadaan hara di dalam tanah mungkin sudah dapat mencukupi kebutuhan tanaman yang diiringi pemupukan melalui tanah, sehingga kedua perlakuan tersebut sekaligus belum mampu menunjukkan perbedaan pengaruhnya satu sama lain terhadap pertumbuhan tanaman.

Hal ini didukung oleh Musnamar (2005), mengatakan bahwa pertumbuhan tanaman tidak menunjukkan perbedaan secara nyata, walaupun tanaman tersebut mendapat perlakuan pemberian pupuk melalui tanah dan daun apabila tanah sudah mengandung unsur hara dan bahan organik yang dibutuhkan untuk pertumbuhan tanaman. 
Selanjutnya Swardi (1985), mengatakan respon suatu jenis tanaman terhadap lingkungan sangat ditentukan faktor lingkungan yang ekstrim seperti intensitas cahaya terlalu tinggi atau terlalu rendah, Hal ini sama terjadi jika keadaaan unsur hara tidak seimbang, kekurangan suatu jenis unsur hara dapat mengakibatkan berubahnya respon tanaman terhadap faktor lingkungan lain.

\section{KESIMPULAN}

Dari hasil analisa statistik perlakuan pengaruh cara pemupukan NPK 15-7-8 bintang kuda laut menunjukkan pengaruh yang nyata terhadap tinggi tanaman umur 3, 5, dan 6 mst, jumlah daun umur 3 mst, tetapi tidak menunjukkan pengaruh yang nyata terhadap tinggi tanaman umur 4 mst, jumlah daun umur 4, 5, dan 6 mst, produksi per sampel dan produksi per plot. Dari hasil analisa statistik perlakuan pupuk supernasa menunjukkan pengaruh yang nyata terhadap tinggi tanaman umur 3, dan 6 mst, jumlah daun umur 4 mst, produksi per sampel dan produksi per plot tetapi tidak menunjukkan pengaruh yang nyata terhadap tinggi tanaman umur 4, dan 5 mst, jumlah daun umur 5 dan 6 mst. Dari hasil analisa statistik perlakuan cara pemupukan NPK 15-7-8 bintang kuda laut dan pemberian pupuk supernasa menunjukkan pengaruh yang nyata terhadap tinggi tanaman umur 4, 5 dan 6 mst, jumlah daun umur 3 mst, tetapi tidak menunjukkan pengaruh yang nyata terhadap parameter tinggi tanaman umur 3 mst, jumlah daun umur 4, 5, dan 6 mst, produksi per sampel dan produksi per plot.

\section{SARAN}

Bagi peneliti yang lain disarankan untuk menggunakan pupuk supernasa dengan dosis yang lebih tinggi dari penelitian ini untuk mendapatkan pertumbuhan dan produksi tanaman jagung yang lebih baik. 


\section{DAFTAR PUSTAKA}

Ahmad Suryana, 2007, Panduan Pengelolaan Tanaman Terpadu (PTT) Jagung, Balai Pengakajian Teknologi Pertanian Sumatera Utara,

Agung S, 2008, Budidaya Jagung Hibrida, Penerbit Agromedia Pustaka, Jakarta

Akil M, 2005, Produksi Biomas dan Biji jagung Pada lahan Kering Melalui Cara Pemberian dan Takaran Pupuk organik, Pusat Penelitian dan Pengembangan tanaman Pangan, Bogor, Hal 157-165

Bahar, FA, 2002, Pembangunan Ekonomi Pedesaan Melalui Pengembangan Jagung, Balai Penelitian Tanaman Serealia,

Buckman, H,O dan N, C, brady, 2000, Prosedur Statistik Untuk Penelitian Pertanian, Penerjemah Endang Syamsuddin dan Justika Baharsyah, UI-Press, Jakarta, Hal 92-100

Dartius, 2001, Dasar Fisiologi Tumbuhan II, Fakultas Pertanian UISU, Medan

Departemen Pertanian, 2007, Pedoman Bercocok Tanaman Palawija dan Sayuran, Badan Pengendalian, Jakarta,

H, Rahmat Rukmana dan H, Herdi Yudirachman, 2007, Jagung Budidaya, Pascapanen dan Penganekaragaman Pangan, CV, Aneka Ilmu, Semarang

Hardjodinomo, 2009, “Ilmu Memupuk” Bandung Bina Cipta.

Lakitan, B, 2002, Dasar-Dasar Fisiologi Tumbuhan, PT, Raja Grapindo Perkasa, Jakarta hal, $6-10$,

Lingga, P, 2004, Petunjuk penggunaan Pupuk, Penebar Swadaya, Jakarta, 21 - 24,

Marsono dan P, Sigit, 2001, Pupuk, Jenis dan Aplikasi, PT,Penebar Swadaya, Jakarta,

Novizan, 2000, Pupuk Akar, Jenis dan Aplikasi, PT,Penebar Swadaya, Jakarta,

Nyakpa, dkk, 2001, Dasar-Dasar Fisiologi Tumbuhan, Penerbit Kanisius, Yogyakarta

Palungkun dan Budiarti, 2001, Meningkatkan Produksi jagung di lahan kering, sawah dan pasang surut, Penebar Swadaya Jakarta

Prawoto, A,A, 2009, “ Botani dan Fisiologi Dalam Panduan Lengkap Kakao Manajemen Agribisnis dari Hulu sampai Hilir, Penebar Swadaya, Jakarta.

Rinsema, 2005, Dasar-dasar Pemupukan, Kanisius, Yogyakarta 
Sutoro, Hadiatmi dan mamiek Setyowati, 2001, Pembangunan Ekonomi Pedesaan Melalui Pengembangan jagung, Balai Penelitian Tanaman Serealia, Jakarta

Srimuldani dkk, 2008, ” Dasar-Dasar Ilmu Tanah” Univ Andalas

Suriatna, S, 2000, Pupuk dan Pemupukan, Mediyatama Sarana Perkasa, Jakarta 